\title{
The Influence of Carnegie Corporation and Teachers College, Columbia, in the Interwar Dominions: The Case for Decentralized Education
}

\author{
Richard Glotzer
}

\section{INTRODUCTION}

In the 1930 s a small network of educators—often with ties to Teachers College, Columbia University, and to progressive education movements in Europe and the North America, and to New York's Carnegie Corporation-began to question the way education was administered in the countries of the old British Empire. Centralization in those countries had produced viable educational systems with British values and culture. The question now was whether progressivist educational theory implied a kind of decentralization in the control and finance of schooling.

\section{TEACHERS COLLEGE, COLUMBIA AND THE CARNEGIE CORPORATION}

Britain's $19^{\text {th }}$ century overseas colonies were centrally governed, as necessitated by thin populations spread across vast geographic distances, and by scarce funds. In education, centralized administration ensured uniform curriculum, teacher training, and facilities. By the 1930 s school inspections, the setting of syllabi and examinations, teacher training, evaluation and promotion, all controlled by centralized bureaucracies, had become irksome to teachers. Solutions would require research, and in the absence of institutionalized research programmes in Britain, the Empire's educators resorted to North America. ${ }^{1}$ In the mid-1920s Teachers College was the preëminent American institution in education. Founded in 1889, it became a selfsupporting division of Columbia University in $1897 . .^{2}$ Under Dean James E. Russell, the College's admissions policy gave preference to older, mature students, often with experience in the field of education. Russell was also known for"talent spotting," admitting educators inclined to lead and to innovate. The best took degrees, then faculty positions.

The "new education" of the 1920 s and 1930s emphasized child development and closer ties between family, community and the school. It decoupled subject matter from pedagogical practice, and saw local control of schools as a demo-

'C. Willis Dixon, A History of the University of London Institute of Education 1932-1972 (London: Institute of Education, 1986), 1-41.

${ }^{2}$ Ronald K. Goodenow and Robert Cowen, "The American School of Education and the Third World in the Twentieth Century: Teachers College and Africa, 1920-1950," History of Education 15, 4 (1986): 271-89; I.L.Kandel, "The International Institute of Teachers College," Teachers College Record 24, 41 (1923): 366-73; James Earl Russell, Founding of Teachers College (New York: Teachers College Press, 1937), 23-69.

(c) Historical Studies in Education/Revue d'histoire de l'éducation 1, nos. 1/2 (2000): 93-111. 
cratic ideal. The movement produced new educational research, stressed leadership roles, and encouraged professional organizations and a professional identity for educators. ${ }^{3}$

Reforms leaders like the University of Chicago's Charles H. Judd, Stanford's Ellwood P. Cubberly, and John Dewey, George Strayer, Paul Monroe, and William H. Kilpatrick, at Teachers College, Columbia, built an informal network, placing students and colleagues in key university positions as faculty and administrators. The network extended into public education, as promotion into administrative positions, particularly school system superintendencies, advanced individual careers and supported a broad programme of educational reform. ${ }^{4}$ Reform emphasized teacher training and more autonomy for teachers in curricular, classroom, and organizational matters. Standardized testing was to provide a scientific indicator of a child's potential, enabling effective teaching. For administrators, innovations in organization, assessment and accountability, and new political roles were features of educational reform.

In 1919 the Progressive Education Association (PEA) was founded by a small group of reformers associated with elite day schools. They sought to provide direction for scattered educational reform experiments. In a decade, the Teachers College, Columbia, presence in the PEA grew dramatically, giving the PEA an activist academic character. ${ }^{5}$

In Europe, the New Education Fellowship (NEF), ran in parallel with the PEA. Founded in 1921 in England, and with branches in most European countries, the NEF led England's reform movement. ${ }^{6}$ The economic downturn after 1918 encouraged conservative domestic policies thwarting reform. The 1918 Education Act called for more purpose-built schools, more teachers, better salaries, limits on child labor, and more emphasis on technical and vocational subjects. By 1922 the Geddes Committee on National Expenditure, responding to deteriorating economic conditions, recommended severe austerity. Budget cuts and layoffs left the 1918 legislation moribund. As conditions improved in the mid-1920s, a consultative committee under W. H. Hadow, produced The Education of the Adolescent (1926). The

${ }^{3}$ Patricia Albjerg Graham, Progressive Education: From Academy to Academe (New York: Teachers College Press, 1967), 17-38; Eric D. Hirsch, Jr., The Schools We Need (New York: Doubleday, 1996), 115-26.

'David Tyack and Elisabeth Hansot, Managers of Virtue (New York: Basic Books, 1982), 129-44.

SSalaries at Teachers College, Columbia, were always modest, and faculty were expected to supplement their salaries through consulting, writing and grants. The PEA provided a broader scope for these activities (personal Communication, Dr. Frank Cyr, April, 1989, Stamford, New York; Dr. Cyr (1900-1995), was a faculty member (1934-1965), and knew many of the people discussed in this article). Lawrence A. Cremin, David A. Shannon, and Mary E. Townsend, A History of Teachers College, Columbia University (New York: Teachers College Press, 1954), 148-75, and Lawrence Cremin, The Transformation of the School (New York: Vintage Books, 1964), 240-91.

${ }^{6}$ L. Zilliacus, "An Analysis of the New Education," New Era 11 (December 1930): 170-4; William Boyd, "The Basic Faith of the New Education Fellowship," in GeorgeZ. F. Bereday and Joseph A. Lauwerys, eds., Education and Philosopby: The Year Book of Education 1957 (Yonkers on Hudson: World Book Company, 1957), 193-208. 
Hadow Report recommended more post-primary places, with non-secondary (academic) students tracked at $11+$ through extensive testing into appropriate post-primary schools. Again, the inadequate number of schools and the uneven quality of existing buildings was at issue. At the onset of Depression in 1929, the school-leaving age remained at 14 , its pre-war limit, and the privileged position of grammar schools remained intact. Thus tough economic times and lack of political will put reform on a slow incremental path in interwar Britain.' If "urchins rolling in the dust," in Churchill's phrase, summed up the conservative view of state education and its reform, restoring the foundations of imperial commerce and power were their favoured preoccupations. ${ }^{8}$ Unsurprisingly, students from the Empire's Dominions and Colonies were attracted to Teachers College, Columbia, especially its International Institute.

Canadians made up the largest group of international students at Teachers College, Columbia. Over twenty-five percent of the nearly four thousand international students who attended between 1923 and 1938 were Canadians, drawn from every region of the country."

In Canada schools and school finance were controlled locally, whereas curriculum and examinations were set at the provincial level. Canadians had become increasingly interested in urban, industrialized school settings since 1918. The search for new forms of education drew in some degree on American progressive educational practices. British Columbia's Putnam-Weir Report (1925), for instance, encouraged testing, placement by ability, introduction of junior high schools, expansion of health and physical education, and greater reliance on research. ${ }^{10}$ Local progressive experiments in the 1920 s reached the provincial level in the 1930s across the West. But Canadians, wary of their larger neighbour, emphasized Dominion status and intellectual links with Britain in the face of American cultural and economic power. ${ }^{11}$

'Gerald Bernbaum, Social Change and the Schools 1918-1944, (London: Routledge and Kean Paul, 1967), 10-97; S.J. Curtis, History of Education in Great Britain (Westport: Greenwood Press, 1971), 322-70; Roy Lowe, "Education in England During the Second World War," in Roy Lowe, ed., Education And the Second World War (London: Falmer, 1992), 4-19.

${ }^{8}$ Barry Eichengreen, Golden Fetters. The Gold Standard and the Great Depression 1919 1939 (New York: Oxford University Press, 1995), 100-124; Robert Skidelsky,Jobn Maynard Keynes. The Economist as Savior 1920-1937 (New York: Penguin Books, 1992), 183-206.

'Robert S. Patterson, “American Influence on Progressive Education in Canada," Jourmal of the Midwest History of Education Society 2 (Fall 1973): 122-41.

10Patterson, "American Influences on Progressive education in Canada;" Peter Sandiford, "Curriculum Revision in Canada," The School 26 (February 1938): 472-77; B. Anne Wood, "Hegelian Resolutions of the New Education Movement: The 1925 Putnam-Weir Report," Dalhousie Review 63 (1984): 254-76.

"Patterson, “American Influences..," cf. Archibald MacMechan, "Canada as a Vassal State, "Canadian Historical Review 1 (1920): 347-53; R.S. Sommerville, ${ }^{\alpha}$ Is Canada Becoming Americanized?," The Empire Review 44 (June, 1926): 537-40; Marion Sheridan, "The Promise of Canadian Secondary Education," Educational Review 69 (April, 1925): 202-08; Nancy M. Sheehan, "Philosophy, Pedagogy and Practice: The IODE and the Schools in Canada, 1900-1945," Historical Studies in Education 2 (1990): 307-22. 
Teachers College, Columbia's South African students, who sometimes went to observe Southern Negro Education firsthand, developed close relations with College faculty and administration. Ties between the College and its South African alumni were formally maintained by a tightly knit overseas alumni group, The Teachers College Club or TC Club. ${ }^{12}$ In the mid-1920s these ties were reinforced by Teachers College's growing relationship with New York's Carnegie Corporation.

In 1923 Frederick P. Keppel became President of Carnegie Corporation. A Columbia graduate, and former Secretary of the Faculty and Dean of Columbia's undergraduate college, Keppel came to Carnegie from the Russell Sage Foundation, having been an undersecretary of war in Woodrow Wilson's Administration. ${ }^{13}$ In 1926, James E. Russell joined Keppel as Special Assistant.

Keppel cultivated talented, energetic, and well-connected individuals for Carnegie-sponsored programmes. Drawn from academia, government, and the arts, these individuals shared a world view grounded in what Keppel termed "the Anglo-Saxon tradition." His operating principle, the "Key man" concept, relied on personal acquaintance and face-to-face meetings, and stemmed from Keppel's belief that "having the right man on the spot" was essential in responding to local developments. " 14 ey men" stayed active in Carnegie-sponsored programmes since associates often had access to funds for research and travel.

Under Keppel, the Corporation's Special Fund broadened its international work, then centred on Canadian higher education. ${ }^{15} \mathrm{Keppel}$ 's diversification was encouraged by another New York based philanthropy, the Phelps Stokes Fund, which had recently extended its interests in Southern Negro Education to Africa. An appreciative Keppel wrote his friend Anselm Phelps-Stokes:

I don't see why you shouldn't charge up Tanganyika and Uganda to the Carnegie account. In fact, if you have time to take a good look at the British Sudan on your way north from Uganda, I don't see why you shouldn't charge every thing but

${ }^{12}$ E. G. Malherbe, "Teachers College and South Africa," manuscript, 1936; E.G. MalherbeCharles T. Loram Correspondence, File 422/2, Ernest Gideon Malherbe Papers, Killie Campbell Africana Library, University of Natal, Durban, S.A. (hereafter E.G.M. Papers); Bram D. Fleisch, "The Teachers College Club: American Educational Discourse and the origins of Bantu Education in South Africa, 1914-1951," PhD thesis, Teachers College, Columbia University, 1995.

${ }^{13}$ Harry Carman, "Dean of Columbia College," in Charles Dollard, ed., Appreciations of Frederick Paul Keppel By Some of his Friends (New York: Columbia University Press, 1951), 1-16

${ }^{14}$ Frederick P. Keppel, Pbilanthropy and Learning (New York: Teachers College Press, 1936), 139-54.

${ }^{15}$ Carnegie Corporation Annual Reports, 1924-28, also John G. Reid, "Health, Education, Economy: Philanthropic Foundations in the Atlantic Region in the 1920 s and 1930s." Acadeniensis 14, 1 (1984): 64-83. 
your incidental visit to the Belgian Congo on us.... As to my own wanderings, it is British Guiana and not New Guinea. ${ }^{16}$

In 1926 Teachers College Professor Mabel Carney, a great favourite of the TC $C l u b$, surveyed education in British Africa, including South Africa and Southern Rhodesia. ${ }^{17}$ Later that year Russell made a similar tour, extending his travels to Britain's Pacific Dominions and Colonies. Based on Carney and Russell's assessment, a first Special Fund grant was made to Kenya Colony in $1926 .{ }^{18}$ (The Fund was now renamed The Dominions and Colonies Fund.) Keppel and Corporation Secretary, James Bertram, retraced Russell's extensive tour in 1927.

For Keppel, the British Empire was not coincident with Anglo-Saxon tradition. The latter was a cultural phenomenon, and for upper-middle-class Americans like Keppel, that culture had informed American heritage, cultural ideals, and club life. Devoted to family and friends, and with a penchant for astute observation, Keppel had a decidedly liberal interpretation of the "white man's burden." The success of small numbers of Black American and "Native" colonial students enrolled at Teachers College, Columbia, under race-blind admissions policies, confirmed for Keppel that the "race problem" was social. By the mid1930s, Carnegie support for such students constituted an important, albeit limited, social experiment. ${ }^{19}$

In the early 1920 s overseas interests were still uncharted territory for United States foundations. They interested themselves usually in rural infrastructure and education, Negro "industrial" education, race relations and public health. ${ }^{20}$ Over fifty percent of Americans lived in rural areas, sometimes under conditions as rudimentary as the South African Veld or the Australian Outback. Rural life, and the localism it spawned, had been debated for decades. Some held that those with promise and energy went to the cities, leaving the mentally feeble, lazy, or morally degenerate in the countryside. This bleak view was countered by the Country Life Movement, its journal Country Life in America, and Theodore Roosevelt's 1910 Country Life Commission, which portrayed rural life as healthy, restful, and - for the affluent - a respite from the congestion, stress, and

${ }^{16}$ Richard Hull, "The Phelps-Stokes Fund, African Education, and Agricultural Underdevelopment in Southern Africa: 1903-1935," Africana Journal 16 (1994): 84-101; Keppel to Phelps-Stokes, December 18, 1931. Box 72, Folder 1191, Phelps-Stokes Papers, Sterling Memorial Library, Yale University.

"Richard Glotzer, "The Career of Mabel Carney: The Study of Race and Rural Development

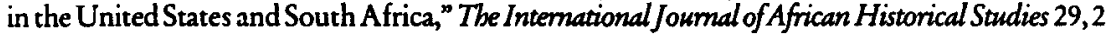
(1996): 309-36.

${ }^{18}$ R. Hunt Davis, "Charles T. Loram and the American Model for African Education in South Africa," in Peter Kallaway, ed., Apartheid and Education (Johannesburg: Raven Press, 1986), 108-126; Clive Whitehead, "Educational Policy in British Tropical Africa: The 1925 White Paper in Retrospect," History of Education 10, 182 (1981): 195-203.

${ }^{19}$ Glotzer, "Mable Carney," op. cit.

${ }^{20}$ Donald Fisher, "Rockefeller Philanthropy and the British Empire: The Creation of the London School of Hygiene and Tropical Medicine," History of Education 7, 2, (1978): 129-43. 
health hazards of urban life. ${ }^{21}$ Nested deeply in this debate were romanticized notions of Jeffersonian Democracy. Local control assured freedom from the constraints of impersonal and uninformed government.

For the average person in rural America the rustic life was not chosen. The automobile, telephone, and radio were relatively new, and the benefits of boldlyfashioned educational legislation were incremental and uneven. One-room schools existed less than an hour's drive from New York City. When Keppel solicited project proposals in Cape Town, he was especially taken by an outline for a comprehensive study of the Union of South Africa's white poor. For Keppel, familiar with Phelps-Stokes's work and the problems of Negro soldiers during World War.I, the analogy between the American South and South Africa was irresistible. ${ }^{22}$

A young University of Cape Town lecturer in Education, Ernest Gideon Malherbe, wrote the research proposal..$^{23} \mathrm{~A}$ tenth-generation Afrikaner and son of a Dutch Reformed Minister, Malherbe held a 1924 doctorate from Teachers College, Columbia, with a thesis on Education in South Africa: $1652-1922 .{ }^{24} \mathrm{He}$ cautioned against growing provincial dependence on Union Government subsidies and the weakening of local interest in schools. Malherbe became the principal investigator and author of the Education volume of the Poor White Commission's Report. Field research began in 1928.

Named Director of the new Bureau for Educational research in 1929, Malherbe left the University for the Civil Service. ${ }^{25}$ The Bureau collected educa-

${ }^{21}$ Richard L. Dugdale, The Jukes: A Study in Crime, Pauperism and Disease (New York: G.P. Putnam's Sons, 1877); Margaret Marsh, "Suburban Men and Masculine Domesticity, 1870-1915," American Quarterty 40, 2 (1988): 165-86.

${ }^{22}$ Keppel was sympathetic to the premise that South Africa's white poor suffered in a world similar to that of poor whites in the American South. The fight for national sovereignty (and its language, Afrikaans) brought ruination in a war against a militarily powerful foe with superior resources. Defeat in the Boer War (1898-1902) led to impoverishment and demoralization among a Protestant people. Moreover, public policy towards Blacks menaced the cultural and racial integrity of the Whites. Frederick Jackson Turner's "frontier thesis” (1924), along with the Union's receptiveness to technological and cultural transfers from North America, and shared Anglo-Saxon racism, was among the supporting arguments for this position. Ralph Hayes, "Third Secretary of War," in Appreciations of Frederick Paul Keppel, 25. See also Martin Leggasick's important analysis of the Frontier Thesis, "The Frontier in South African Historiography," in Shula Marks and Anthony Atmore, eds., Economy and Society in Pre-Industrial South Africa (London: Oxford University Press, 1980),44-79. For discussion of race and cultural transfers, see Paul Rich, Race and Empire in British Politics (Cambridge: Cambridge University Press, 1986).

${ }^{23}$ For an account of the Poor White Commission's field work see E.G. Malherbe's pictorial autobiography Never a Dull Moment (Cape Town: Juta \& Co, 1982), 119-78; also Report of the Carnegie Commission on the Poor White Problem in South Africa, Vols.I-V (Stellenbosch: Pro Ecclesia, 1932).

${ }^{24}$ Ernest Gideon Malherbe, Education in South Africa:1662-1922 (Cape Town: Juta \& Company, 1923). See also R. Hunt Davis, "The Administration and Financing of African Education in South Africa 1910-1953," in Apartheid and Education,127-38.

${ }^{25}$ Bram Fleisch, "Social Scientists as Policy Makers: E.G. Malherbe and the National Bureau for Educational Research, 1929-1943," African Studies Institute, Witwatersrand University, 1995. 
tional statistics and directed Union Government projects, flourishing during the 1930 s with Carnegie support. By 1935, Canada was the only dominion without a Carnegie-supported educational research institute.

The Poor White Commission's report was published in five volumes in 1932. This done, Malherbe spent part of 1933 in North America on a Carnegie grant to investigate "On what formula shall one allocate state subsidy to education so as not to penalize the poorer areas unduly, and at the same time to stimulate and encourage local initiative? ${ }^{26}$ Malherbe took his inquiry to Canada, bringing his former Teachers College office colleague Paul Mort, now a member of the College faculty and a specialist in school finance. In Canada they were guests of well-known educator Fred Clarke, previously Malherbe's department head at Cape Town, and now head of McGill's Faculty of Education. ${ }^{27}$

Having struck up a friendship with Keppel on his 1928 visit to Cape Town, Clarke occasionally visited Keppel and Teachers College, Columbia, developing a close friendship with Isaac Kandel, Head of the International Institute. (Although both were English-raised and educated, Clarke's class origins and Kandel's Jewish background made advancement in England difficult.) Clarke's intellectual prowess aside, his intuitive insight and talent for synthesis made him a Carnegie associate worth cultivating. ${ }^{28}$ With (white) unemployment edging toward 300,000 in South Africa, the implications of the Poor White Commission's report were hotly debated. Malherbe's respite in North American was brief.

South Africa was in July 1934 the site of an international conference on "poor whitism," among other matters. ${ }^{29}$ Like the founding of the South African NEF, the conference was a Malherbe "brain wave." The theme, "Educational Adaptations in a Changing Society," had wide appeal. Affluent urbanites learned of school experiments in Chicago's suburban Winnetka, and the latest advances in

${ }^{26}$ Malherbe Grant Proposal. August 28, 1932; E.G. Malherbe Correspondence, Box 209, Grant Series I, Carnegie Corporation Archives, Butler Library, Columbia University, New York, hereafter CC.

${ }^{27}$ Richard Glotzer, "Sir Fred Clarke: South Africa and Canada Carnegie Corporation Philanthropy and the Transition from Empire to Commonwealth," Education Research and Perspectives 22, 1 (1995): 1-21; Peter Kalaway, "Fred Clarke and the politics of vocational education in South Africa, 1911-29," History of Education 25, 4 (1996): 353-62. See also Clarke's "Canada and South Africa. An Essay in Comparative Interpretation and a Plea for An Imperial Institute of Education," Yearbook of Education (London: Evans Brothers, 1933), 500-17, and "The Prospect for Canadian Education," The McGill News 16 (Spring 1935): 20-24.

${ }^{28} \mathrm{Cf}$. Fred Clarke, Quebec and South Africa: A Study in Cultural Adjustment, printed lecture, 11 June 1934 (University of London, Institute of Education, 1934).

${ }^{29}$ What Keppel had endorsed in 1927 as a comprehensive social science inquiry for South Africa, now gave further momentum to a rising tide of ethnic nationalism, positing that in this "white man's country," Afrikaners bore the brunt of [white] ethnic and economic discrimination. In October of 1934, the Relief Council of the Dutch Reformed Churches brought 500 delegates to Kimberly for a discussion of white poverty. This "Volkskongres" stressed ethnic self reliance, public works to alleviate [white] poverty, the establishment of a national social welfare agency, and redundancy for "Non Europeans" to create jobs for whites. 
child-centred education. John Dewey and Harold Rugg, influential members of the PEA, accompanied by Mabel Carney, came from Teachers College, Columbia, at Carnegie expense. Prominent members of the NEF came from England and Continental Europe. An unqualified success, the conference put South Africa on the map as a progressive country committed to modern social science techniques in solving social problems. ${ }^{30}$

Fred Clarke presented Canadian developments at the NEF later in 1934. A Canadian presence at the 1931 and 1932 meetings assured that Canadian educational developments were discussed at subsequent international NEF forums. In the late 1930s, Canadian progressives, assisted by the PEA and Carnegie Corporation, hosted three smaller NEF conferences in Toronto, Hamilton, and Windsor, with about 3,500 people attending. Coming on the eve of World War II, these conferences led nowhere, nor was there a research bureau to help. ${ }^{31}$ For Malherbe, the 1934 Conference set the stage for comparative research with Paul Mort.

\section{ADMINISTRATIVE CONTROL AND RURAL SCHOOL FINANCE}

By the early 1930s Paul Mort had become an important authority on the financing of public education. ${ }^{32}$ Active in the PEA, he sought Federal funding for American state education, a controversial stance since many believed Federal support invited Federal control. Mort wondered how variously wealthy and populous states could Equitably provide school programmes. Mort's ideas Drew on the earlier contributions of Ellwood P. Cubberley, his graduate school advisor, George D. Strayer, and Robert M. Haig. Building on the Strayer-Haig Model, Mort believed some minimum level of education should be common to all localities. ${ }^{33}$ State and local taxes should fund such programmes, with local tax rates adjusted to the economic circumstances of a community. Just as within states there were communities widely disparate in ability to support education, so were there poor and wealthy states. Where earlier research stressed equali-

\footnotetext{
${ }^{30}$ See E.G. Malherbe, ed., Educational Adaptations in a Changing Society (Cape Town: Juta $\&$ Co, 1937).

${ }^{31}$ Regional conferences were held in collaboration with the PEA in Buffalo (1935) and Toronto (1937). In 1938 NEF Conferences were held in Hamilton and Windsor.

${ }^{32}$ Mort began teaching at 16 in a one room school in Indiana. Completing a B.A. degree at 21 , he became a school principal and superintendent. Recruited by Russell in 1920, Mort came to Teachers College, Columbia, completing an M.A. in 1922, and Ph.D. in 1924. He then joined the faculty. Personal communication, Dr. Frank Cyr, April, 1989, Stamford, New York. Dr. Cyr (1900-1995) a student of Mort's, was similarly recruited while a young school superintendent in Nebraska. He is best remembered as "the father" of the yellow school bus.

${ }^{33}$ Cubberley's equalization model contained "reward for effort" provisions favoring wealthier school districts of which Mort strongly disapproved. Robert J. Garvue, Modern Public School Finance (New York: Macmillan and Co, 1969), 224-9; Percy E. Burrup, Vern Brimley Jr,Rulon R. Garfield, Financing Education in a Climate of Change (Boston: Allyn \& Bacon, 1993), 165-79; Ellwood P. Cubberley, School Funds and Their Apportionment (New York: Teachers College Press, 1906); George D. Strayer and Robert M. Haig, Financing of Education in the State of New York (New York: American Council on Education, 1923).
} 
zation and foundation programmes, Mort's work stressed local initiatives and the identification of key (usually affluent) districts for setting contribution levels of other districts.

Mort devised methodology for measuring acceptable minimum school programmes and calculating funding for equalization. Two books, State Support for Public Education (1935), and Federal Support For Public Education (1936), set out Mort's ideas. ${ }^{34}$ Sparsely populated school districts often operated small schools spread over wide areas, foregoing the economies of scale of larger schools or school consolidation. (Less populated districts might require more teachers than more populated ones.) Using regression analysis, Mort statistically estimated teacher/ pupil ratios based on school attendance and size. Separate equations for primary and secondary schools refined computing the average number of teachers a district required. ${ }^{35}$ Thus "weighted" pupils were elements in equalization formulas.

Mort had assisted Malherbe with his Carnegie application. Now Malherbe encouraged Mort to visit South Africa, where equalization and innovation could be observed under different social and governmental conditions. ${ }^{36}$ In early 1935 Mort drafted a proposal for a Carnegie support. His exploratory study matched up-to-date schools in American and South African communities, comparing how locally-controlled and financed schools, and centrally-financed and controlled schools, maintained minimum academic programmes, and engaged in innovation.

Adopting the concept of "cultural lag" from his Columbia colleague economist Rexford Tugwell, Mort's "minimal lag" described the least amount of time needed for dissemination of an educational idea or practice. Keppel and Russell reluctantly agreed with the outside reviewer, Lotus Coffman, a Teachers College alumnus and President of the University of Minnesota, that Mort's application was "poorly stated and illy drawn. ${ }^{37}$ Mort revised to meet their objections. ${ }^{38}$

Arriving in South Africa in March, 1936, Mort visited South African Education schools and rural administrations. ${ }^{39}$ Mort's research appeared as Adaptability of Public School Systems (1938), ${ }^{40}$ a prototype for studies of the Dominions. Adapt-

\footnotetext{
${ }^{34}$ Paul A. Mort, State Support for Public Education (Washington: American Council on Education, 1935); Federal Support for Public Education (New York: Bureau of Publications, Teachers College, Columbia, 1935).

${ }^{35}$ Mort, State Support for Public Education, 90-128.

${ }^{36}$ Mort to Malherbe, 18 November 1932. Mort/Malherbe Correspondence, EGM Papers.

${ }^{37}$ Russell to Coffman, 17 February 1936; Coffman to Keppel, 13 February 1936; Coffman to Russell, 20 February 1936. All three W.F. Russell Papers, Grant Series 1, CC Files. (J.E. Russell and W.F. Russell were father and son.)

${ }^{38}$ Michael White noted the same pattern for Australian grants. "Carnegie Philanthropy in Australia in The Nineteen Thirties-A Reassessment," History of Education Review 26:1 (1997): 1-24.

39"Bekende Amerikaanse Onderwysman Kom Unie Ondersoek Doen," 4 March 1936; "Hoe Die Laer-En Hoerskole Van Amerika Finansieel Ondersteun Word," 11 April 1936. Both articles, Die Volkstem. File 422/2, EGM Papers.

${ }^{40}$ Paul A. Mort and Frances G. Cornell, Adaptability of Public School Systems (New York: Teachers College, 1938). Cornell taught in the Department of Educational Administration, and was not involved in the South African aspect of the project.
} 
ability departed from conventional educational research, offering comparisons between five American states and South Africa's four provinces that were hard to follow. It was a ground-breaking if clumsy exercise. "Adaptability included Mort's Guide for Self Appraisal of Schools, listing 183 specific adaptations education experts agreed were desirable educational practices, along with a criteria for recognizing adaptations.

Adaptability asked about circumstances under which school systems integrated individual adaptations, or adopted adaptation itself as ongoing practice. Adaptation meant "the sloughing off of outmoded purposes and practices by school systems and the taking on of new ones to meet new needs. ${ }^{\text {m42 }}$

Mort found financially-starved local governments supported increased centralization of authority and funding for schools. Teachers opposed extended local taxation powers since provincial control had brought higher salaries and stable working conditions. Teachers supported national funding and standards for certification, as the teaching profession was an avenue of upward mobility. Intrigued by the apparent ability of schools to innovate without a strong local tax base, Mort wanted to examine South African Schools more closely. Perhaps Malherbe had underestimated local initiative when he wrote that

[school] control has become so highly centralized that nearly all local initiative with regard to education has been smothered...people locally are becoming... indifferent to their local school. It is now the State's school and Captain pays for all. ${ }^{43}$

Mort's research was well received. The provincial education departments offered cooperation and logistical support for an expanded proposal (1936-37), although critical of Mort's initial emphasis on urban schools. ${ }^{4+}$ The Council of Provincial Administrators recommended assigning school inspectors to the project. Mort's final proposal compared matched samples of 40 urban communities in South Africa with 120 American communities. Matched rural schools were also now included. Mort would bring three research assistants to South Africa for six months, hiring a fourth in the United States for another six months, and acquiring the personal services of a fifth assistant for twenty months. The provinces were each to appropriate $£ 500$ (\$2500) to send a school inspector to the United States for four months of training. Malherbe would take leave from the Bureau for just under a year, with Mort's grant subsidizing travel for his family. It was a grand plan-and expensive.

${ }^{41}$ The four states were New York, New Jersey, Pennsylvania, North Carolina, and Delaware. The contradictions between equalization and segregation in the two societies were overwhelming and Mort generally avoided them. In the American South, "States' Rights" advocates opposed the Federal role Mort advocated. In Gains vs. Missouri (1938) the United States Supreme Court ruled that segregated facilities were required to be equal, leaving the door open for compliance inspections.

${ }^{42}$ Adaptability, ix.

${ }^{43}$ Note 23, Malherbe grant Proposal.

"Paul Mort, "A Proposed Study of One Aspect of the Problem of School Support" [Loca] versus Central Support in Relation to the Ease or Difficulty of Adaptation to New Needs]. Carnegie Corporation, 1937. Mort File, Grant Series 1, CC. 
Mort's initial budget of $\$ 75,500$ was too rich for Keppel: "What he has in mind ...is a $\$ 75,000$ job. ${ }^{m+5} A \$ 62,700$ budget followed, with reduced plans for six months of field work. Keppel, wary of an expensive project in South Africa, hesitated. The Corporation's support for the new South African Institute for Race Relations (1929) had brought public rebuke from Prime Minister Hertzog.

Keppel tabled the proposal. Malherbe applied political pressure by registering the disappointment of the Interprovincial Consultative Committee, set up by the Union's four Education Directors. ${ }^{46}$ They had anticipated Mort's expertise in revising funding formulas for the provinces. Mort continued his lobbying efforts while Malherbe promised to sound out colleagues at Australian and NewZealand NEFs conferences he was scheduled to attend later in the year. He lobbied Keppel on this account as well. Australia and New Zealand, of growing strategic importance to Great Britain and the United States, were receiving increasing attention from Keppel, who himself toured the Southern Dominions in $1935 .^{47}$

\section{DECENTRALIZATION IN AUSTRALIA AND NEW ZEALAND}

James E. Russell's 1928 visit had laid the ground work for Carnegie activity in the Pacific Dominions. Corporation associates compiled an extensive list of 125 modern [American] books in Education and Psychology, many written by the College Faculty. Collections were offered gratis to Teacher Training Colleges, Universities and Directors of Education in Australia and New Zealand ${ }^{48}$

Just as Keppel and Russell recognized the importance of the Union of South Africa for the African continent, they viewed Australia and New Zealand in strategic terms. (An Anglo-American navel treaty in the Pacific replaced an AngloJapanese one in 1924. $)^{49}$ Russell put the matter succinctly to Keppel, arguing that both were "experiment stations for all English speaking peoples":

Here is a great continent... bound to play a great role in world affairs as affecting the Pacific. It is blood brother to us and will always be a "white man's country." It is trying out problems in democracy which..must inevitably be an example to us. It is an integral part of a ring around the Pacific beginning with Canada and

${ }^{45}$ Ibid, 4; Keppel/Mort Blue Sheet, 5 November 1936. Mort File, Grant Series 1, CC.

${ }^{46}$ Malherbe to Keppel, 27 March 1937. EGM 1-209.

"If no "native question" permeated public discourse in Australia, policies toward Aborigines were hardly more enlightened. In the late 1920 s public outcries following massacres at Coniston and Forrest River led to government inquiries. When C. Hartley Grattan surveyed 150 prominent Australians for the Institute of International Affairs in 1940, the majority listed the "White Australia" policy among the prominent aspects of Australian life they would like Americans to understand. .Malherbe to Keppel, 18 August 1936, Mort Papers, CC, also C. Hartley Grattan Papers, Box 18, File 1, Harry Ransom Humanities Research Center, University of Texas at Austin.

${ }^{48}$ Distribution of Books file, Box 50, Grant Series One, CC, for an overview of the Library Program see White, note 32.

"Mary Boyd, "Australia-New Zealand Relations," in William S. Livingston and Wm Roger Louis, eds., Australia, New Zealand and the Pacific Islands Since the First World war (Austin: University of Texas, 1979), 47-61. 
our West Coast and running on to Hawaii, New Zealand, Australia and the Philippines. We can't ignore it without loss to ourselves. The time is ripe for closer contacts and the safest way is through educational agencies. ${ }^{50}$

In Australia the Corporation cultivated associates from the educational establishment. "Below the line," as Keppel put it, the Corporation confronted entrenched bureaucracies and a complacent civil service resistant to change.

Frank Tate, Director of Education for South Australia, was the Corporation's most prominent associate in the 1930s. A distinguished educator who had come up through the ranks, Tate got on well with Russell and Keppel. In the 1920s he had investigated education in Fiji, been an Australian representative at the 1923 and 1927 Imperial Education conferences, and a member of the 1929 Southern Rhodesian Education Commission where he had worked with Fred Clarke. ${ }^{51}$

At the end of Russell's 1928, Tate agreed to write a proposal for a research bureau similar to Malherbe's in South Africa. ${ }^{32}$ In a December, 1928, meeting in Sidney, Tate called for individual state research institutes, affiliated with a central institute charged primarily with administrative tasks. In the fall of 1929 he was awarded a $£ 150,000$ grant and $£ 12,500$ for administrative expenses. In April of 1930, the Australian Council for Educational Research (ACER) came into being, with Kenneth Cunningham, a 1927 Teachers College, Columbia PhD, and friend of Keppel's, as executive officer.

Cunningham approached Keppel about ACER serving as a stimulus for a similar body in New Zealand. Keppel liked the idea, cautioning that New Zealanders themselves should apply for grants. Tate and Cunningham met with colleagues in Auckland, and a New Zealand Council for Education Research (NZCER) was established with Carnegie support in $1934 .^{53}$

"The Anglo-Saxon tradition," and Keppel's scrupulous avoidance of political involvement, papered over Anglo-American conflicts of interest. Drained by the Great War, the Empire was fragile. Carnegie support helped keep the Dominions educationally alive, yet dependent. ${ }^{54}$

Clarke visited the Southern Dominions at Carnegie expense in 1935 in preparation for his move to the University of London's recently established Institute of Education. Organized as a counterpart to Teachers College, Columbia, both the Institute and its residential subsidiary, London House, were heavily subsidized by Carnegie Corporation. Struck by local conservatism, Clarke under-

${ }^{50}$ Russell to Keppel, 2 April 1928. Grant Series One, Box 316.

${ }^{51}$ R.J.W. Selleck, Frank Tate: A Biography, (Melbourne: Melbourne,1982), 266-7.

${ }^{52}$ Tate to Butler, 5 June 1928; Tate to Keppel, 4 July 1928; J.E. Russell to Tate, 15 October 1928, All letters B.4903, Vol.34, CC.1928-35. Archives, Australian Council of Educational Research.(Hereafter ACER.)

${ }^{53}$ W.F. Connell, The Australian Council for Educational Research 1930-80 (Victoria: Australian Council for Educational Research, 1980), 80-4.

${ }^{54}$ Robert Boyce, "Canada and the Pacific Cable Controversy, 1923-28: Forgotten Source of Imperial Alienation,"Joumal of Imperial and Commonwealth History 26, 1 (1998): 72-92; J.E. Lee and Martin Better, The Colonial Office War and Development Policies (London: Temple Smith, 1982), 25-38. 
estimated public willingness to entertain change and the ability of the new Councils to build constituencies. C. Hartley Grattan, an American Carnegie fellow in Australia (1936-37) later wrote that the 1930s was a time of awakening national consciousness in both Dominions, visible in a growing nationalism. ${ }^{55}$ The growing number of influential individuals travelling and studying overseas under Carnegie Grants would also have an impact. The New Zealand and Australian NEF Conferences of 1937 were thus helpful to public education.

As 1937 drew to a close, NZCER released Leicester Webb's The Control of Education in New Zealand (1938), a Carnegie-funded study of the history and evolution of New Zealand's educational system. Webb acknowledged the benefits of centralization-universal elementary education, wider interest in secondary schooling, better quality teachers, and uniform standards for grading and school inspections. Ironically, he noted, these benefits found their origins in a system intended to be decentralized. The 1877 Act left Elementary and Secondary education separate entities, with a Department of Education for coordination. This division of authority, combined with the expansive tendencies of bureaucracy, placed increasing power in the centralized Department, leaving local authorities with uninspiring tasks and uninspired leadership. For Webb, the devil was in the details.

Over time, local and central authorities had wandered into the wrong domains. A central Board of Education set syllabi, organized curriculum and judged teacher suitability. School inspectors followed rigid standards of evaluation for teacher competence and student progress. For teachers and inspectors alike, promotion involved climbing the Central Board's lengthy career ladders. Conforming to precedent assured promotion, and real authority came late in one's career.

With little financial or clerical support, local authorities undertook few substantive activities, and were directed into lines of activity like building construction, best left to a professional department. In Webb's view, local bodies should be responsible for educational decisions, particularly those which reflected the nuances of local economies and social structure. Adjustments in syllabi, teacher selection and opportunities for innovation, should all be local prerogatives.

Reformist in tone and critical of current educational practices, Webb's book got a mixed reception from professionals. The Control of Education required close reading, and was inaccessible to lay readers. However, Webb's study laid a groundwork for subsequent research by Isaac Kandel.

In June 1937, Kandel arrived in New Zealand for a six-month study of educational administration. Kandel was drawn into both NEF Conferences despite his reservations. ${ }^{56}$ The following year Kandel's Types of Administration with Parti-

${ }^{55}$ Grattan is generally credited with bringing Australia (and New Zealand) into the consciousness of the American public. See Grattan's Introducing Australia (New York: J.M. Day, 1942), and Laurie Hergenhan's biography of Grattan, No Casual Traveler (Queensland: Queensland University Press, 1993).

${ }^{56}$ See Lawrence A. Cremin, Isaac Leon Kandel (1881-1965) A Biographical Memoir (New York: National Academy of Education, 1966). 
cular Reference to the Education Systems of New Zealand and Australia (1938) appeared. Kandel also prepared a private document for Keppel and the Carnegie Trustees, Report on New Zealand and Australia (1938), far more critical than the published report. ${ }^{57}$

Kandel's work benefited from Webb's analysis and his own broad comparative framework. In the United States and Great Britain, cooperation between localized administration and centralized authority grew from the practice of democracy. Australia and New Zealand's systems, while sharing democratic tenets, had become overly centralized. Kandel was blunt, arguing that bureaucratic rules encouraged mediocrity. As Sir Keith Hancock had put it; "The instinct of Australian Democracy is to make merit take a place in the queue." 58

Centralization, Kandel argued, went too far in prescribing the details of the educational system. Teacher ratings should be abolished, training upgraded and moved to the universities, and curriculum development localized. With school inspections abolished, inspectors might be redeployed as consultants. The central authority would still cover the costs of the system, but would be collaborative. ${ }^{59}$ Structural changes were not ends in themselves; conceptual and attitudinal changes were what mattered.

For conservative audiences, Kandel satisfied expectations of what an overseas "expert" should be. Others felt obliged to shock audiences. Malherbe recalled years later how the University of Glasgow's William Boyd brought Peter Fraser to his feet, protesting that he could not tolerate insults hurled at him and his educational system. The astonished Boyd had been speaking about Scotland. Australian educators were told that seniority and senility were almost equivalent when used as a basis for promotion. ${ }^{60}$

The Australian NEF Conference met from August 4 th to September $18^{\text {th }}$ in seven major cities. Nearly nine thousand people subscribed, in addition to the thousands of tickets sold for individual lectures. The lectures, reflecting the progressive orientation of most of the speakers, were later published as Education for Complete Living (1938). The foreword, by Frank Tate, was a carefully constructed discussion of over-centralization.

Tate acknowledged the traditional benefits of centralization but wrote approvingly of devolution of authority in English education.

${ }^{57}$ Isaac Kandel, "Report on New Zealand and Australia," February 1938. Grant Series 1, CC.

${ }^{58}$ Isaac Kandel, Types of Administration with Special Reference to Australia and New Zealand (Melbourne: Melbourne University Press, 1938), 62-3.

${ }^{59}$ Ibid., 82-90.

${ }^{60}$ See Malherbe's remembrances of the NEF Conferences in Never a Dull Moment,191-210; F.W. Hart, "Criticisms of Education in Australia," in K.S. Cunningham and W.C. Radford, eds. Education for Complete Living (Melbourne: Melbourne University Press, 1938), 661-4. 
As...inspectors have ceased to exercise power, they have acquired more...influence in the schools.... Their strength is shown in their power to encourage and stimulate..."

Kandel considered Tate and Cunningham too cautious. James E. Russell, reading Kandel's Report on New Zealand and Australia from his Florida retirement, suggested the research bureaus had helped achieve national consensus for change. ${ }^{62}$

The only start that could have been made [by Tate and Cunningham] was on a purely impersonal basis. N.Z. is a swell state but simple. Australia is a continent... the jealousy between..states would not tolerate any probing into their peculiar idiosyncrasies. ..the institute [ACER] has been most tactful in giving its first attention to problems that are universal, leaving each the inducement to selfcriticism... the prelude to self-improvement.... Mr. Tate's common sense has been invaluable. $^{63}$

Malherbe followed Tate's lead. In Centralization and Decentralization, he suggested Australia's national government accept responsibility for equalization. ${ }^{64}$ Malherbe announced his (and Mort's) plan to compare the United States and the three centralized dominions.

His keen interest in the Australian NEF conference aside, Keppel remained ambivalent about Mort's project. ${ }^{65}$ The Carnegie Trustees, who generally followed Keppel's lead, took unusual interest in the proposal. A review of Mort's book, requested by trustee Walter Jessup, decided the issue. Written by William Carson Ryan, head of the Carnegie Foundation for the Advancement of Teaching and President of the PEA (1937-39), the review was scathing: "Starting out with a bias in favour of both Mort and Teachers College, I am distressed with what I find. The book seems incredibly bad." ${ }^{\text {"66 }}$

Had Ryan been constructively critical, and there was much to criticize, Mort's proposal might have survived. Ryan missed the experimental and pioneering character of the research, noting Adaptability of Public School Systems "...used scientific terms and supposedly scientific methods for material that does not lend

${ }^{61}$ Ibid., xiii-xxi.

${ }^{62}$ Malherbe's Bureau had faced similar problems and generated support for the Bureau by using the same agenda. Russell to Keppel, 21 February 1938, Grant Series 1, CC.

${ }^{63}$ Ibid, Russell to Keppel, 21 February 1939.

${ }^{\circ}$ Malherbe, "Centralization and Decentralization," Education for Complete Living, 277-90.

${ }^{65}$ From the mid 1920 s, Keppel worked to reduce costly long term commitments freeing funds for new projects. In August, 1937, Keppel began negotiations with Gunnar Myrdal, a University of Stockholm Political Economist, about conducting a comprehensive study of "the Negro in the United States," published as AnAmerican Dilemma: The Negro Problem and Modem Democracy (New York: 1944). Henry James, "President of Carnegie Corporation," in Appreciations of Frederick Paul Keppel, 46-65. See also Ellen Condliffe Lagemann, The Politics of Knowledge (Chicago: University of Chicago Press, 1989), 123-46.

${ }^{66}$ W. C. Ryan to W. Jessup, 27 May 1938. Mort Papers, Grant Series 1, CC. 
itself to that treatment." He ignored Mort's extensive A Guide for Self-Appraisal of School Systems, later published separately. ${ }^{67}$

Probably unaware of Ryan's review, Mort knew he was on shaky philosophical grounds. The interventionist implications of progressive and "New Deal" policy and planning of the 1930s was worrisome to conservatives. Malherbe had written Clarke of Mort's apprehension.

[T] here are... Carnegie Corporation people who are strong federalists... who would oppose... any effort that might lead to the undermining of the sovereign responsibility of the individual States. They regard Mort's theories of equalising [sic] opportunity between the states as a thin edge of the wedge in ultimately leading to federal control as well as support of education. Mort... very strenuously denies the implication of control because he envisages a system, by which the federal government will give equalizing subsidy to the states on a formula without control. ${ }^{68}$ In Adaptability of Public School Systems Mort had described the need to study comparative centralized and decentralized administrative systems. An examination of each was the next logical step in theory construction. In Fall 1938, Francois Cillie, a Carnegie Fellow for 1937-38, arrived at Teachers College, Columbia, fresh from a year at the Institute of Education. Cillie, on the faculty of the Pretoria Technical College, worked with Mort in South Africa.

Cillie's task was to compare the centralized New York City Public Schools with decentralized outlying school districts. ${ }^{69}$ Mort and Cillie hypothesized that specific types of innovations and adaptations prospered best in decentralized systems, others in centralized systems, while others prospered independently of administrative configuration. This broad theoretical perspective grew directly from Mort's South African field research. Comparisons between New York's centralized administration and decentralized outlying districts would be more substantial than Mort's earlier piecemeal observations. The Mort-Cillie research design also showed decentralization and democratization were not necessarily synonymous. The press for a strong and wealthy centralized state, especially in a time of ascendent fascism and impending war, was undeniable. Yet local initiative and community participation were functional and symbolic expressions of participatory democracy and education. ${ }^{70}$

From Mort's $A$ Guide for self-Appraisal of School Systems (1937), one hundred and seventy-six items deemed "desirable educational practices" were identified. One hundred items fared equally under either type of administration, with 56 items faring better in decentralized communities and 20 faring better in centralized communities. ${ }^{1}$ Over half of the adaptations prospered under either system. Teacher improvement, enrichment and extension of curriculum, standards for

${ }^{67}$ Paul Mort and Francis Cornell, A Guide for Self-Appraisal of School Systems (New York: Teachers College, Bureau of Publications, 1937).

${ }^{68}$ Malherbe to Clarke, 29 January 1937. Unaccessioned File, Malherbe-Clarke Correspondence, 1925-51, EGM Papers.

${ }^{69}$ Francois Cillie, Centralization and Decentralization (New York: Teachers College, Bureau of Publications, 1940), 6-7.

${ }^{70}$ Ibid., 5.

${ }^{71}$ Ibid., 96. 
personnel, accommodation of special needs students, and school-community cooperation, fared equally well under both systems. Analysis of the remaining 76 items brought surprise findings.

Although decentralized schools were more amenable to innovation and adaptation, centralized schools, with their more extensive resources and organization, were better at implementing innovations and keeping them. New York City's centralized administration was more likely to target innovations and adaptations for poorer schools based on need than decentralized districts. The introduction of controversial subjects also fared better in centralized schools since teachers had more job security, and were less vulnerable to community pressures. Centralization favoured teachers' economic security as Mort's South African findings showed.

Decentralization, Cillie found, better coped with particular circumstances of schools, teachers and students, especially at the elementary level. Individualizing instruction, classroom freedom, using student records for diagnostic and planning purposes, developing civic consciousness, and revitalizing the teaching of traditional subjects, also fared better under decentralization. ${ }^{72}$

The evidence favouring decentralization was hardly overwhelming. A subsequent analysis of Cillie's innovations notes there was a higher proportion of pedagogic to administrative innovations. Had the sample bias been reversed, and the two types of administration remained consistent with and to the innovations they favoured, Cillie might have concluded that centralized districts were more innovative. ${ }^{73}$ As it was New York City's centralized administration was quite responsive to innovation. The theory that decentralized authorities served communities best, now required modification-and research.

The coming of war made Cillie's the last Carnegie project on decentralization. Across the Commonwealth, educational experts turned to war related work or were seconded to other government departments. In 1943 Keppel died, removing the central figure from the semi-formal "old boy/old girl" Carnegie network. Personal ties, crucial to network functioning, would be reëstablished by Keppel's successor. In 1945 the world was a different place, and decentralization a lower priority for the renamed Commonwealth Fund.

${ }^{72}$ In the category "democratization," five items concerned development and use of new methods and materials by teachers. Cillie believed they "reached to the very root of the difference between centralized and decentralized systems of education." These items indeed prospered best under decentralization but did not correlate with related categories. Cillie was perhaps confusing democratization with professional autonomy.

${ }^{73}$ Brian Holmes, "Policy Formulation, Adoption and Implementation in Democratic Society," in Jon Lauglo and Martin McLean, eds., The Control of Education (London: Institute of Education, 1985), 65-85. 


\section{CONCLUSION}

Movement toward the administrative decentralization of education came first from the Dominions themselves. In Canada, urbanization, immigration and economic development, encouraged cautious experimentation with new educational ideas and practices within a decentralized framework. In interwar South Africa, white ethnic nationalism complicated matters. In Australia, the long reign of State department heads contributed to the isolation of educational bureaucracies from their communities, and large numbers of young men who might have become energetic young teachers and administrators, were lost in the Great War.

Teacher interest in regional NEF meetings was thus a bellwether of desire for experimentation. The new "research institutes" encouraged "grass roots" interest in reform, providing direction, a programme, and a call to action. Carnegie Corporation, and its Teachers College, Columbia associates provided the inspiration and financial means for advancing research council programmes, subtly influencing educational debate in the Dominions. "Key men" served as gate keepers, mobilizing local resources, influencing public opinion, research agendas, grant-making and, ultimately, public policy. Their activities were not incompatible with loyalty to Britain or growing feelings of dominion nationalism. This was an international reform movement, encouraged by national systems, and not externally imposed. ${ }^{74}$

In the interwar period only Canada departed from the pattern set in the other dominions. The Corporation's Annual Report for 1935 noted that “[Canadian] ...programs are so closely interwoven with the corresponding activities in the United States as really to form a single whole. ${ }^{375}$ That assessment, in this instance, was optimistic. Without a national research council, the activities of the Canadian NEF, tied as they were to the PEA and sustained by Carnegie support, lacked national prestige and authority. ${ }^{76}$ The progressive program, under criticism in the United states by the 1940s, had only a modest impact on Canadian education.

In Britain, meanwhile, short-sighted policies and strong belief in the preëminence of British cultural and intellectual institutions meant intellectual opportunities in North America went unnoticed.

The interwar movement to decentralize education produced educational and social ideas that were subsequently popular in national education reform movements. It encouraged a stronger voice for teachers in schools. And finally, schoolbased management and funding, placing budgetary, curricular and personnel responsibilities at the school level, popular in the late $20^{\text {th }}$ century, find their origins in these long-ago schemes and controversies."

${ }^{74} \mathrm{C}$. E. Beeby to the author, 20 January 1995; E.G. Malherbe to the author, 20 August 1981; Adrian Smuts to the author, 13 September 1983.

${ }^{7}$ Carnegie Corporation, Annual Report, 1935, 37.

${ }^{76}$ Donald Fisher, The Social Sciences in Canada (Waterloo: Wilfred Laurier University Press, 1991), 5-40.

"Allan Odden and Carolyn Busch, Financing Scbools for High Performance, (San Francisco, Jossey-Bass Publishers, 1998), 26-44, 71-92. 